\title{
A Controlled Study of Oral Vigabatrin $(\gamma$-Vinyl GABA) in Patients with Cerebellar Ataxia
}

\author{
A.M. Bonnet, M. Esteguy, G. Tell, P.J. Schechter, J. Hardenberg, Y. Agid
}

\begin{abstract}
Vigabatrin ( $\gamma$-vinyl GABA; GVG), an irreversible inhibitor of GABA-transaminase, at a daily dose of $2-4 \mathrm{~g}$, and a placebo were each administered orally for 4 months to 14 patients with cerebellar ataxia $(9$ with Friedreich's ataxia, 5 with olivopontocerebellar atrophy), in a double-blind, placebo-controlled crossover study. For the group as a whole, there was no significant difference between the GVG and placebo periods in any of the parameters of cerebellar symptomatology measured. Individually, one patient showed some improvement after 3 months of treatment with $2 \mathrm{~g} /$ day GVG. Tolerance to $4 \mathrm{~g} /$ day GVG was poor, whereas $2 \mathrm{~g} /$ day was well tolerated. The results suggest that agents which increase central GABA concentrations are not likely to be of benefit to patients with Friedreich's ataxia or olivopontocerebellar atrophy.
\end{abstract}

RÉSUMÉ: Dans une étude en double aveugle avec permutation croisée, 14 patients présentant une ataxie cérébelleuse (9 ataxies de Freidreich et 5 atrophies olivopontocérébelleuses) ont reçu alternativement du vigabatrin ( $\gamma$-vinyl GABA; GVG), inhibiteur de la GABA transaminase à la dose de 2 à 4 g par jour, et du placebo, pendant deux périodes successives de 4 mois. Pour le groupe dans son ensemble, l'analyse n'a pas mis en évidence de différence d'effets entre le vigabatrin et le placebo, et ce, quel que soit le paramètre symptomatologique. Sue le plan individuel, un seul patient a été amélioré après 3 mois de GVG à $2 \mathrm{~g} /$ jour. La tolérance au GVG a été médiocre pour $4 \mathrm{~g} /$ jour alors que la dose de $2 \mathrm{~g} /$ jour a été bien tolérée. Ces résultats suggèrent que les agents induisant une augmentation centrale de GABA sont peut susceptibles d'améliorer les patients porteurs d'ataxie de Friedreich ou d'atrophie olivopontocérébelleuse.

Can. J. Neurol. Sci. 1986; 13:331-333

Decreased concentrations of $\gamma$-aminobutyric acid (GABA) and glutamate have been found at post-mortem examination in the cerebellar hemispheres and vermis of patients with Friedreich's ataxia. 'Thus, an obvious therapeutic strategy would be to attempt to increase GABA concentrations in these areas. Vigabactrin ( $y$-vinyl GABA; GVG) is a specific, enzymeactivated, irreversible inhibitor of GABA-transaminase ${ }^{2}$ which increases CSF GABA concentrations proportionally to the dose following oral administration in man. ${ }^{3,4}$ The vigabatrin-induced alterations in CSF biochemistry are thought to reflect similar changes in brain. ${ }^{5}$ The dramatic beneficial effects of vigabatrin in reducing seizure frequency and severity in drug-refractory epileptic patients ${ }^{4,6,7}$ associated with these increases in CSF GABA further support the idea that GABA concentrations are increased in brain. In an open study in 10 patients with cerebellar ataxia ( 9 with Friedreich's ataxia), oral vigabatrin treatment produced equivocal improvement in cerebellar symptomatol- ogy, although some amelioration was found in a majority of cases. ${ }^{8}$ Therefore, a controlled double-blind trial appeared warranted.

\section{SubJECTS AND MethodS}

Fourteen consenting patients ( 9 males), aged 16 to 55 years, entered the study. All patients had well-documented and reproducible cerebellar symptomatology. Nine patients suffered from typical Friedreich's ataxia (FA) and 5 from olivopontocerebellar atrophy (OPCA) of Menzel's type (Table 1). Four of the 5 patients with OPCA had a positive family history for their disease. The stage of the disease, after Pourcher and Barbeau, ${ }^{9}$ ranged from 2 to 4 for the FA patients and 2 to 3 for the OPCA patients. Concomitant medications are listed in Table 1.

Using a double-blind, placebo-controlled crossover design, patients were randomly assigned to two 4-month periods of

From the Clinique de Neurologie et Neuropsychologie Hôpital de la Salpêtrière. Paris, France (Drs. Bonnet. Esteguy and Agid) and the Merrell Dow Research lnstitute, Strasbourg. France (Drs. Tell, Schechter and Hardenberg)

Received March 27. 1986. Accepted June 16. 1986

Reprint requests to: Dr. Y. Agid, Hôpital de la Salpêtrière, 47, boulevard de l'Hôpital, 75013 Paris, France 


\begin{tabular}{|c|c|c|c|c|c|}
\hline Patient No. & Age/Sex & Diagnosis & Stage* & Duration & Concomitant medications \\
\hline 1 & $55 / \mathrm{M}$ & $\begin{array}{l}\text { Olivopontocerebellar } \\
\text { atrophy (Hereditary) }\end{array}$ & 2 & $3 \mathrm{yr}$ & \\
\hline 2 & $28 / \mathrm{F}$ & $\begin{array}{l}\text { Olivopontocerebellar } \\
\text { atrophy (Hereditary) }\end{array}$ & 3 & $8 \mathrm{yr}$ & $\begin{array}{l}\text { Tanakan } 3.6 \mathrm{~g} / \text { day (extract of ginkgo biloba) } \\
\text { Lorazepam p.r.n. } \\
\text { Vitamin } B_{1.6 .12} \text { suppl. }\end{array}$ \\
\hline 5 & $28 / \mathrm{M}$ & Friedreich's ataxia & 4 & $20 \mathrm{yr}$ & Quinine $660 \mathrm{mg} / \mathrm{day}$ \\
\hline 6 & $33 / \mathrm{M}$ & Friedreich's ataxia & 4 & $16 \mathrm{yr}$ & \\
\hline 7 & $18 / \mathrm{M}$ & Friedreich's ataxia & 2 & $5 \mathrm{yr}$ & \\
\hline 8 & $29 / \mathrm{F}$ & Friedreich's ataxia & 4 & $13 \mathrm{yr}$ & Tanakan $3.6 \mathrm{~g} /$ day (extract of ginkgo biloba) \\
\hline 11 & $54 / \mathrm{F}$ & $\begin{array}{l}\text { Olivopontocerebellar } \\
\text { atrophy (Hereditary) }\end{array}$ & 2 & $8 \mathrm{yr}$ & Oxazepam $50 \mathrm{mg} /$ day \\
\hline 12 & $24 / \mathrm{M}$ & Friedreich's ataxia & 4 & $10 \mathrm{yr}$ & \\
\hline 13 & $46 / F$ & $\begin{array}{c}\text { Olivopontocerebellar } \\
\text { atrophy }\end{array}$ & 2 & $10 \mathrm{yr}$ & \\
\hline 14 & $22 / \mathrm{M}$ & Friedreich's ataxia & 3 & $10 \mathrm{yr}$ & \\
\hline
\end{tabular}

*after Pourcher and Barbeau, 1980

treatment beginning with either $4 \mathrm{~g}$ /day of GVG (powder contained in sachets of $1 \mathrm{~g}$ each) or $4 \mathrm{~g} /$ day placebo (lactose plus 1 $\mathrm{mg}$ quinine for taste-masking). Crossover to the alternate therapy was abrupt. GVG and placebo were administered twice daily, dissolved in water. If an adverse reaction was suspected, the dose of study drug could be cut by half without breaking the treatment code.

On the first day of the study and at months 2, 4, 6 and 8, patients underwent the following clinical examinations: 1) physical and neurological examination, 2) functional staging of ataxia ${ }^{9}$, 3) scoring of cerebellar syndrome disability , 4) a "tapping"" test on a two-unit Adams Labratory Counter for 20 seconds with one finger of each hand, 5) writing a standard sentence and drawing an Archimede's spiral 3 times, 6) measuremènt of time needed to walk 10 metres and return, and 7) measurement of time the patient could stand without support with legs together and eyes closed. Additionally, the investigator rated overall improvement at the end of each 4-month treatment period. Biological controls on blood and urine samples were performed prior to study entry and after each 4-month treatment period.

\section{RESUltS}

Tolerance to GVG treatment was poor with 4 patients prematurely withdrawn from the study because of suspected drugrelated unwanted effects. Reasons for withdrawal included a fall, possibly preceded by a seizure (Patient 2 ), an increase in the severity of myoclonus resulting in a fall (Patient 6), the occurrence, on 2 occasions, of facial clonus followed by a loss of consciousness (Patient 9), and drowsiness (Patient 12). Patients 6, 9 and 12 were receiving $4 \mathrm{~g} /$ day $\mathrm{GVG}$ at the time of discontinuation while Patient 2 was receiving 2 g/day GVG. In all cases, these unwanted effects occurred during the first week of GVG administration.
Because of the severity of suspected side effects, it was decided to decrease the daily dose of the study drug in all patients still receiving it. In four patients $(3$ of whom had specific complaints; patients 1,8 and 13, Table 2) this dose reduction occurred during the GVG period. In 4 patients ( 2 of whom had specific complaints; patients 2 and 5 , Table 2) it occurred during the placebo period.

The effects of GVG therapy on cerebellar symptomatology are presented in Figure 1. The data from the four patients who were withdrawn are not included. No significant difference was observed between the GVG and placebo periods $(\mathrm{N}=10)$ on any of the parameters observed. Individually, one patient with OPCA (Patient 11) was clearly improved during the final month of treatment with a $2 \mathrm{~g} /$ day GVG; fewer falls and improved equilibrium were reported in this patient. No noticeable change was observed in the other patients during therapy with $\mathbf{4} \mathrm{g} /$ day GVG, 2 g/day GVG, or placebo.

Investigator ratings of overall improvement during the active treatment period were minimally improved in 2 patients (Patients 11,13 ), unchanged in 9 (Patients 1, 3, 4, 5, 7, 8, 12 and 14) and worse in 3 (Patients 6, 9, 10).

Nodifference was found in the performance tests ("tapping", writing, walking or standing) with GVG therapy compared to placebo.

No clinically significant changes were noted in any of the biological parameters measured.

\section{Discussion}

The potential beneficial effects reported in the open trial using $2 \mathrm{~g} /$ day $\mathrm{GVG}^{8}$ were not confirmed in the present study. It was expected that any potential benefit would be more obvious in the present study given the higher dose of GVG used (4 $\mathrm{g} /$ day) and the increased duration of treatment ( 4 months com- 
LE JOURNAL CANADIEN DES SCIENCES NEUROLOGIQUES

\begin{tabular}{|c|c|c|c|}
\hline Patient No. & $4 \mathrm{~g} /$ day GVG & 2 g/day GVG & Placebo \\
\hline 1 & $\begin{array}{l}\text { Dizziness } \\
\text { Drowsiness } \\
\text { Asthenia }\end{array}$ & none & $\begin{array}{l}\text { Drowsiness, } \\
\text { Increased severity of nystagmus }\end{array}$ \\
\hline 2 & (a) & $\begin{array}{l}\text { Facial clonus } \\
\text { Possible seizure (b) }\end{array}$ & Anorexia \\
\hline 5 & $\begin{array}{l}\text { Constipation } \\
\text { Insomnia } \\
\end{array}$ & (a) & $\begin{array}{l}\text { Insomnia } \\
\text { Nervousness }\end{array}$ \\
\hline 6 & $\begin{array}{l}\text { Increased severity of myoclonus, fall } \\
\text { with leg fracture (b) }\end{array}$ & (a) & (a) \\
\hline 8 & Dizziness & Shortness of breath & none \\
\hline 12 & Drowsiness & Drowsiness (b) & $\begin{array}{l}\text { Drowsiness } \\
\text { Fatigue }\end{array}$ \\
\hline 13 & Localized dermatomycosis & Poor memory & Poor memory \\
\hline
\end{tabular}

(a) never received dose

(b) discontinued prematurely

(c) drug interrupted for 1 week

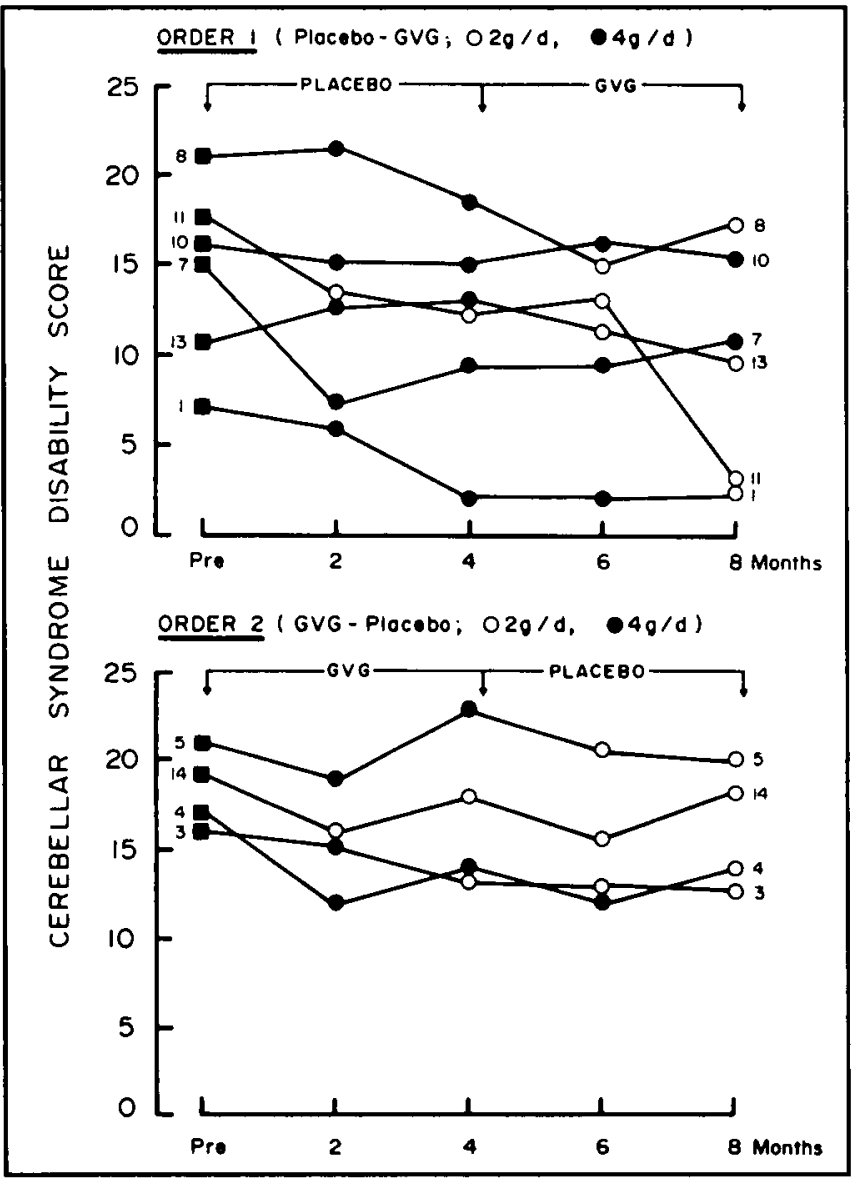

Figure 1: Individual cerebellar syndrome disability scores prior to study ( and during treatment with $2 g(O)$ or $4 \mathrm{~g}(\bullet)$ of GVG or placebo. The maximum possible score is 30 . Numbers are patient identification. pared to one month). This, however, was not the case, with only one patient showing some benefit and then only after 3 months of therapy with 2 g/day GVG. The severity and frequency of side effects associated with $4 \mathrm{~g}$ /day GVG may have masked any potential positive effects in some patients, but no improvement was observed in patients who tolerated $4 \mathrm{~g} /$ day reasonably well. Although GVG was administered at doses shown to increase human CNS GABA concentrations, ${ }^{3.4}$ the possibility remains that GABA was not modified sufficiently at relevant synapses to elicit a measurable clinical response. Nevertheless, these results suggest that agents which increase gabaergic neuronal activity are not likely to improve degenerative cerebellar ataxia such as those observed in Friedreich's ataxia and olivopontocerebellar atrophy.

\section{REFERENCES}

1. Huxtable RJ, Azari J, Reisine T, et al. Regional distribution of amino acids in Friedreich's Ataxia brains. Can J Neurol Sci 1979; 6: 255-258.

2. Jung MJ, Lippert B, Metcalf BW, et al. $\gamma$-vinyl GABA (4-aminohex-5-enoic acid), a new selective inhibitor of GABA-T: effects on brain GABA metabolism in mice. J Neurochem 1977; 29: 797-802.

3. Grove J, Schechter PJ, Tell G, et al. Increased gamma-aminobutyric acid (GABA), homocarnosine and $\beta$-alanine in cerebro-spinal fluid of patients treated with gamma-vinyl-GABA. Life Sciences 1981; 28: 2431-2439.

4. Schechter PJ, Hanke NFJ, Grove J, et al. Biochemical and clinical effects of gamma-vinyl-GABA in patients with epilepsy. Neurology $1984 ; 34: 182-186$.

5. Grove J, Palfreyman MG and Schechter PJ. Cerebrospinal fluid GABA as an index of brain GABA activity. Clin Neuropharmacol 1983; 6: 223-229.

6. Rimmer EM and Richens A. Double-blind study of $\gamma$-vinyl GABA in patients with refractory epilepsy. Lancet 1984; 1: 189-190.

7. Gram L, Klosterkov P and Dam M. $\gamma$-vinyl GABA: a double-blind placebo-controlled trial in partial epilepsy. Ann Neurol 1985; 17: 262-266.

8. De Smet Y, Mear JY, Tell G, et al. Effect of Gamma-vinyl-GABA in Friedreich's ataxia. Can J Neurol Sci 1982; 9: 171-173.

9. Pourcher $\mathrm{E}$ and Barbeau $\mathrm{A}$. Field testing of an Ataxia scoring and staging system. Can J Neurol Sci 1980; 7: 339-344. 